\title{
Introduction: China, the European Union and the developing world: analysing and comparing a triangular relationship region by region
}

\section{Matthieu Burnay, Jean-Christophe Defraigne and Jan Wouters}

\section{CHINA GOES GLOBAL AND RESHUFFLES THE BALANCE OF INFLUENCE ACROSS THE REGIONS OF THE DEVELOPING WORLD}

By the late 15th century, China's economy had become essentially inward-looking as the Chinese leadership embraced self-centred and isolationist notions in managing their territory. Due to its sheer size, China remained the largest economy in the world until the mid-19th century and the Chinese market exerted significant influence on international trade. Pomeranz has shown how the Chinese demand for silver enabled Europe to gain a dominant position in international trade through its exploitation of American colonies and helped Europe avoid development deadlocks, facilitating the rise of industrialisation (Pomeranz 2000). Nevertheless, contrary to Western European powers, China's role remained passive: it did not seek to control the international trade system. Between the 16 th and the late 19th centuries, through colonisation or gunboat diplomacy and thanks to their institutional innovations, the modern Western European powers created a new world economy in which feudal entities of the non-Western world were forced to participate by opening up to trade and investment driven by Western merchants and companies. In that process, China lost a substantial part of its national sovereignty and did not play an important role in world affairs until 1945.

Under the leadership of the Communist Party of China (CPC), China developed a strong centralised state that enabled it to recover its national sovereignty and launch an industrialisation process. Despite many upheavals and some disastrous policies, notably the Great Leap Forward and the 
Cultural Revolution, in just three decades China modernised its public goods, that is, education, infrastructure, health and security, and developed a skilled labour force and a solid industrial base which were to be the foundations of its remarkable growth from the 1980s until the 2010s. After two decades of relative autarky, the CPC decided to open up the economy to international technology and managerial know-how in order to upgrade its development capacities through foreign direct investment (FDI) and trade. China's growth was spectacular as it exploited its comparative advantage and the development of its huge domestic market. In terms of output growth, China under Mao performed rather well. Chinese growth rates were above those of countries like Argentina or India but nevertheless below Brazil's or Thailand's (Defraigne 2012). Chinese development was essentially autarkic, however. Given the substantial decline of its share of world trade in the 1960s and 1970s and the absence of Chinese outward direct investment, China's impact on the world economy was negligible. By contrast, the opening of the Chinese economy and its exceptional growth has generated a massive and growing impact on the world economy. Even though China's growth from the 1980s to the 2000s was driven more by investment than by exports, its industrialisation and transformation into the so-called workshop of the world - driven by outsourcing and FDI from multinational enterprises (MNEs) globalising their production processes - meant that China quickly became a major consumer of commodities and a major exporter of manufactured goods across the globe. The Chinese economy's performance started to radically transform the trade patterns of the world economy and its accession to the World Trade Organization (WTO) in 2001 further accelerated this phenomenon.

The on-going global strategy that seeks to transform China's national champions into global MNEs and that has been pursued by the Chinese authorities since the late 1990s generated an exponential growth of Chinese outward direct investment in the 2000s. Chinese firms began to open subsidiaries in the developing world and to compete with the incumbent Western firms in fields like energy products, engineering, construction, utilities, telecoms or household appliances. The stock of Chinese FDI remains very limited compared to European or US stocks, but the rise of Chinese FDI flows has been impressive. Like many industrialised countries which support the internationalisation of their national firms, China has used tied aid programmes to facilitate the commercial penetration of its national champions and to obtain public procurement contracts in different regions of the developing world.

China's transformation into an outward-looking economy has required it to play a more active role in global governance and to develop a global 
diplomacy. China is now part of the main international fora (e.g. G20) and international organisations (e.g. WTO, UN Security Council). In addition, it positions itself as a central international actor in its bilateral relations with the core members of the international community. The low-profile diplomacy advocated by Deng Xiao Ping at the beginning of China's economic reforms is not an option anymore. The recent stance taken by China on the crisis in Syria and the triple use of its veto right show that China is ready to defend its interests and foreign policy values at a high cost. Nevertheless, China remains what David Shambaugh has rightly labelled a partial power (Shambaugh 2013). The low profile maintained by China in the Doha Development Round at the WTO, contrary to the one taken by Brazil and India for instance, shows that China still adopts a low profile in certain key global governance institutions.

China's rising economic and diplomatic influence might challenge the position of European powers in the developing world, where the European Union (EU) and its Member States often occupy a well-entrenched position at the economic, diplomatic or strategic level. This incumbent position is explained by long historical ties, notably as a result of colonisation but also due to the fact that European firms began the internationalisation of their activities in the late 19th century, some one hundred years before their Chinese counterparts. European MNEs benefit from much longer experience in international management, from a deeper knowledge of local specificities and from long-lasting political and business ties with most developing countries. European powers have also developed a military presence in some parts of the developing world, notably in Africa and the Middle East, while China is only launching the very first step of international expansion of its military capacities. Naturally, European economic and diplomatic influence also varies considerably across the different regions of the developing world due to long-term historical factors or to the level of economic complementarity. Finally, if one has to compare European and Chinese influence in the different regions of the developing world, one must analyse not only commercial penetration but also the historical ties and the geopolitical configuration and rivalries in these regions.

\section{PROVIDING A REGION-BY-REGION COMPARATIVE ANALYSIS}

The present volume delves into such evolutions in order to provide a comparative analysis of Chinese and EU (as well as its Member States') influence across five different regions of the developing world: Asia-Pacific; South and Central Asia; the Middle East and North Africa; Sub-Saharan 
Africa; and Latin America. The analysis of the triangular relationship between China, the EU and the developing world fills an important gap in academic literature. While there is a broad acknowledgement that the importance of China is rising across the developing world, this book offers a comprehensive and comparative account of the relative increase of the Chinese presence in the various regions of the developing world and highlights its impact on the relationship between the EU and these regions. It shows how the rise of China affects the relations between these regions and Europe. A select cast of authors presents a systematic assessment of the various economic, diplomatic and historical ties between China, the $\mathrm{EU}$ and the regions at hand in order to compare the relative importance of each region for the two actors.

The term 'developing world' has been chosen because this book focuses on economies that are not considered as mature in terms of technological development and business internationalisation as the US, Western Europe or Japan. However, the term has its obvious limits as it covers countries with extremely heterogeneous levels of development and political systems. How can one compare the challenges faced by such diverse economies as Singapore, Algeria and Congo? The regions covered by this book comprise emerging economies with large global firms such as India, South Korea, Brazil or Turkey, but also least developed countries and intermediate economies. Despite the disparity between these economies taken individually, at a regional aggregate level the five areas analysed all contain a majority of non-OECD economies which share common characteristics in their relations with the EU and China that distinguish them from North America, Europe or Japan. In that sense, they belong to what could be called the 'global South'.

A multidisciplinary approach is used to take into account the disparate economic, institutional, geopolitical and historical dimensions and in order to provide a comprehensive view of the triangular relationship for each of the five regions considered. The book puts the rising influence of China in the developing world into perspective and reveals how EU relations with these five regions are being reshaped as a result. The indepth comparative analyses and case studies help to identify the common patterns and specificities of the triangular relationship in each region, allowing the reader to go beyond the generalisations, simplifications and stereotypes that fail to distinguish the variable degrees of importance of each of these five regions for China and the EU.

In a first substantive chapter Jean-Christophe Defraigne provides a long-term historical perspective of China's and Europe's relationship with the developing world from centuries past to the 20th century.

Part II concentrates on the Asia-Pacific region, which is the most 
essential region from the point of view of China and the region where European influence is strictly limited. The chapter by Elena AtanassovaCornelis outlines the situation in Northeast Asia, notably the Korean and Taiwanese cases. As this book focuses on developing economies, the three following chapters are dedicated to Southeast Asia and ASEAN. Wenjia Wang presents the state of play of EU-ASEAN and ChinaASEAN relations, respectively. David Camroux looks into the impact of the rise of China and the adoption of the 'pivot' strategy by the US on EU-ASEAN relations. Katja Weber contributes a case study on the divergent approaches by the EU and China on the issue of human security in Myanmar.

Part III presents the situation in the other regions directly neighbouring China, specifically South Asia, with two chapters focusing on India and Central Asia. Ummu Salma Bava outlines how the rise of Asia has reshaped the strategic and economic relations of India with China and the EU. Jivanta Schöttli looks at how the three actors reshape their aspirations and alliances in the multilateral system of a multipolar world. Fabienne Bossuyt analyses the evolution of China's and the EU's economic and development aid flows in different economies of Central Asia in order to provide a picture of China's rise in the region which has allowed it to become a key player over the last two decades.

Part IV is dedicated to the Middle East and North Africa region. The chapter by Karima Fachqoul and Jean-Christophe Defraigne highlights the heterogeneity and the complex specificities of the region regarding its relations with the EU and China, revealing the importance of strategic alliances in the post-colonial Cold War era. In-depth case studies on the Maghreb by Thierry Pairault, on Iran by Clara Portela and on Libya by Ronald Bruce St John follow this chapter.

Part V deals with the situation in Sub-Saharan Africa. Benjamin Barton and Ariane de Bellefroid present the state of play of Chinese and EU influence in the region. The chapter by Chris Alden and Laura Barber focuses on how the triangular relations are impacting African development. Finally, the chapter by Bob Kabamba offers a case study on the Democratic Republic of Congo.

Part VI looks into Latin America. Gilles Verhulst analyses the trade and investment triangular relations, whereas Sophie Wintgens' chapter explains the different elements that account for the perception of China's rising power in the region. 


\section{THE EU, CHINA AND THE REGIONS OF THE DEVELOPING WORLD: RELATIONS WITH VARIABLE LEVELS OF INTENSITY}

Through the chapters that outline the state of play in each region and specific case studies, this book highlights the great diversity of relationships between the EU, China and the developing world. The significance of exports and imports, the size of investment flows, the comprehensiveness of the institutional framework in which the relationship is taking place, the prioritisation of bilateral over multilateral cooperation as well as the scope for deepening and strengthening the ties strongly vary depending on the region that is being studied. It can be submitted that this diversity is conditioned by various factors that explain the nature and strength of the relationship between China/the EU and developing countries. These factors will be summarily dealt with below: they include historical ties, the nature of the political regime of the country, the geographic location, institutional arrangements and strategic changes that affect the region considered.

\section{Historical Ties and the Nature of the Political Regime}

The first factor is clearly the depth of historical ties. The colonial expansions of European powers have generated long-term economic ties that have produced strong political and cultural influences as well as an incumbent position for European firms for decades. These are only progressively being eroded by the rise of other powers, first the US and now other emerging powers, notably China. The duration and penetration of colonisation has varied across regions and constitutes a decisive factor in explaining the different levels of European influence in the various regions.

Another key element has been the capacity of developing countries to gain political autonomy from former colonial powers and/or from the West during and after the Cold War. In these countries, the role of European investors and institutions was more limited, leaving room for the development of Chinese interests. Often, these countries had a long history of confrontational relations with Europe and the US. Most of the time, they developed a strong state that controlled trade, investment and domestic politics, rejecting the Western model of market economy and multiparty parliamentary regimes. The political nature of these countries has often generated human rights violations. The EU and its Western allies that promote their dominant common political and economic model and the respect of multilateral rules (that they have mostly designed themselves) have managed to considerably reduce the capacity of these 
countries to have access to strategic assets, to military technology, to development aid and to their markets. For these nationalist states, especially the ones which are in permanent tension with the EU and the US, China can serve as an alternative ally, aid donor or trade partner, helping them to break away from their relative isolation, avoid international sanctions or even prevent military intervention (Syria, Iran or North Korea). The examples of Zimbabwe and Sudan are particularly telling in this respect. In the former case, there has even been a Chinese veto in the United Nations Security Council on a draft resolution imposing sanctions upon Zimbabwe for gross human rights violations (Draft Resolution S/2008/447) (Wouters and Burnay 2013). Sub-Saharan Africa and the Middle East and North Africa (MENA) region are other cases where this factor is particularly decisive, but it is also relevant for some countries in other regions, like Myanmar, North Korea and Venezuela, as a number of chapters highlight.

From a Chinese point of view, the shared experience of colonialism can strengthen the ties between China and some developing countries through the creation of a common 'victim identity'. However, the economic role of China is increasingly that of an exporter of manufactured products and of an aid provider, whereas its partners in the developing world, even advanced and large economies like Brazil or Indonesia, are mainly suppliers of commodities. As many contributions in this book show, the development of such 'North-South' relations progressively weakens the credibility of this specificity of China's diplomacy.

\section{Geographic Proximity}

Geographic proximity is also a key factor that justifies the interests of China and the EU to be more or less involved in the economic and geopolitical realities of a particular region. It triggers for both actors strategic thinking when engaging with the developing world. In that sense, the close neighbourhood of East Asia to China means that this region remains the main destination of China's foreign direct investments. Geographic proximity, as well as historical ties, also explains the central role played by China in multiple crises involving North Korea. Another example relates to the trade-security nexus that is central when one wants to understand the importance of China's presence in Central Asia. Part of the Chinese investments in the region can indeed be understood as serving China's attempt to secure the Xinjiang region in the north-western part of the country.

Nevertheless, this factor does not account for major economic relations, especially with the increasing globalisation of the world economy 
since the 1980s. As China has become the workshop of the world and one of the top-three producers of manufactured products and has experienced the largest wave of urbanisation in the history of mankind, it has become increasingly reliant on the rest of the world for food, raw materials and energy. The scale of these import requirements goes far beyond the export capacities of China's neighbouring economies. It has required the PRC to develop trade and investment links with regions that are well endowed in terms of commodities, such as the Middle East, Sub-Saharan Africa and Latin America, who have never been traditionally important trade partners of China. Furthermore, the EU's presence in East Asia remains important despite geographic distance because of the importance of the markets of these economies and their capacity to develop a comparative advantage in the assembly of high-tech products - two factors which explain the important EU trade and FDI flows in East Asia. However, long distance EU investment flows are more efficiency- (reducing production costs by internationalising EU firms' production processes) and market-seeking than resource-seeking, while for China they remain mostly resource-seeking, reflecting the more advanced stage of EU MNEs compared to Chinese MNEs.

\section{Institutional Arrangements}

The existence of bilateral or multilateral agreements facilitates trade, investment and aid flows. The different contributions to this volume show how the proliferation of free trade agreements explains in part the rising intensity of trade flows between the EU, China and the developing world. In this field, the EU has more experience in designing deep WTO+ trade agreements since the 1990s with its neighbours (Turkey, Eastern Europe, the Mediterranean), and through the 'competitive liberalisation' process that resulted from the stalemate of the Doha Round. The level of development, the role of the state in the Chinese economy and China's still limited experience in international trade negotiations explain the gap in terms of reaching formal agreements that are WTO-consistent. Nevertheless, China is learning fast how to use WTO rules and instruments. The PRC's 2001 entry in the WTO has had a tremendous impact on China's commercial presence and economic interdependence with other WTO Members, notably developing and reinforcing new long-distance trade relations. China is also using less traditional bilateral agreements to secure access to raw materials and public procurement contracts in different regions of the world. Bilateral aid programmes by China but also the EU or its Member States strengthen economic and strategic relations, notably for the least developed economies. 


\section{Strategic and Political Changes}

The local geopolitical context affects the possibility for the EU and China to influence and become key actors in a specific region. The example of the Arab Spring is particularly telling in this regard. The respective influences of the EU and China have been reshuffled by the political upheavals in the MENA region, in the case of Libya and Syria forcing both actors to redefine their strategies and become more involved in the process.

The changes in the strategy of the US, the still uncontested global strategic leader, also play a key role in redefining the respective relations of China and the EU with the various regions. The US 'pivot' towards Asia will naturally affect China by countering its rising influence in East Asia but it will also modify the position of the EU and European powers in their neighbourhood, notably in the Mediterranean, the MENA and Eastern Europe. In cases like Iran or Myanmar, a US change could offer these isolated governments a possibility to diversify their economic and diplomatic relations, reducing their dependence visà-vis China.

\section{UNDERSTANDING THE COMPLEXITY OF THE RELATIONS OF THE EU AND CHINA WITH THE DEVELOPING WORLD}

The variety of relationships also clearly puts forward the necessity to endorse a multi-actors/multi-sectors approach when analysing the triangular links between the EU, China and the developing world.

While until the 1980s the PRC's relations with the rest of the world could be understood by analysing the strategy of the leadership of the Communist Party of China (CPC), the liberalisation of trade and the progressive economic decentralisation of the domestic economy have generated a more complex picture with the emergence of private Chinese enterprises and non-Chinese MNEs operating in China, relatively more autonomous provincial government and State Owned Enterprises (SOEs). It is necessary to point out the crucial role played by China's national champions in key industries and notably in mining and energy, most of them still SOEs. These SOEs have grown increasingly independent through the process of opening up and reforming the country. FDI flows cannot simply be understood through a grand strategy developed by the CPC. Nevertheless, because of the weaknesses of property rights and the political nature of the PRC, SOEs still maintain tied relations with the state in a way that is not comparable with their counterparts from the EU 
or other OECD economies. Other actors such as provincial governments or private firms also play a role in developing ties with the different regions analysed.

EU strategies towards each region are even more difficult to assess because of the institutional complexity of EU institutions, with various degrees and types (supranational/intergovernmental) of power, the variety of actors and the contradictory objectives of EU Member States.

The largest EU Member States, like France, the United Kingdom and Germany, maintain bilateral dialogues in addition to the EU one. Member States with specific trade interests also try to secure their presence in certain countries. It is, for instance, true for countries hosting major oil companies (i.e. France, the UK) that they invest more time and energy in their relationship with countries in Central Asia. In addition, the existence of diverging views and interests of the various EU institutions should not be underestimated. For instance, the European Parliament has a tendency to be more vocal on human-rights-related issues, while the European Commission arguably takes a more interests-driven approach towards external action. These differences highlight the challenge of matching discourse(s) with action and the difficulty of ensuring the coherence of EU external action.

Furthermore, private enterprises are far more important in developing trade and investment flows on the EU side and they enjoy far greater autonomy in their international operations. EU-based MNEs have been present in all the world's regions for decades, even more than a century for some. They can operate independently of their national governments or the EU institutions. One needs to understand their global and regional strategies to understand the economic flows between the EU and the regions concerned.

Despite the complexity of this myriad of actors involved in building relations with the different regions of the developing world and their emerging economies, one can still identify some key differences in the way EU and Chinese officials formulate their relationship to the developing world.

First, the Chinese government does not want to surrender the advantage it draws from its developing country status in global governance. It wants to preserve its relationship with the developing world in terms of South-South cooperation, while the EU clearly accepts the North-South dimension of its relationship with the developing world. In practice, it is nevertheless more accurate to talk about a North-South type of relationship, with China seeking to import fossil fuel and primary commodities and exporting more specialised and manufactured goods from and to Africa, the MENA region, Southeast Asia or Latin America. Securing 
access to raw materials is indeed one of the main Chinese foreign policy priorities aimed at sustaining its fast economic growth rate.

Second, and related to the idea of promoting a different cooperation dynamics with the rest of the world, China still endorses a foreign policy rhetoric that includes the five principles of non-intervention: mutual respect for sovereignty and territorial integrity; mutual non-aggression; non-interference in each other's internal affairs; equality and mutual benefit; and peaceful coexistence. At a time when the EU is increasingly keen to promote intervention in the affairs of third states in case of severe threats against civilian populations and massive human rights violations, China - and many other non-Western countries - opposes the doctrines of humanitarian intervention and of the responsibility to protect. This defensive perspective on sovereignty explains to a large extent the very different perspectives on some of the main contemporary international crises, including the one in Syria. Nevertheless, in the long run this nonintervention policy could prove more difficult to follow if China continues its economic development and if its largest firms pursue their internationalisation and continue to invest overseas at the rate of the last decade.

Third, while China tends to promote a bilateral approach when engaging with the developing world, the EU tends to adopt a more multilateral/ holistic approach that takes into account the impact on the neighbouring countries as well as the impact on regional integration processes. This policy is partly linked to the willingness of the EU to promote 'effective multilateralism' and to support initiatives that enhance regional integration processes. This policy is nevertheless being continuously readjusted, partly due to failures to engage with some regional organisations. Indeed, the EU has failed to achieve its goals through engaging with the Association for South East Asian Countries (ASEAN) or the CAN, although it still hopes to conclude an Association Agreement with Mercosur. Following these failures, the EU has readjusted its approach from regionalism to a stronger emphasis on bilateral relations with the main countries of the various regions, for instance Chile, Brazil, Mexico, South Africa, Turkey, Israel, Singapore or South Korea.

Fourth, another key difference is to be found in the way in which the EU and China implement their respective aid strategies. Although there is great heterogeneity in the way the EU and its Member States strategically plan and implement their development policies, the conditionality attached to EU development policy strongly differs from China's almost non-conditional development policy. This relative absence of conditionality is also linked to the fact that Chinese aid directly serves the economic interests of China, in many ways inspired by some features of the development policies pursued by Japan in the 1970s and 1980s but also by some 
EU Member States in their bilateral development programmes (notably France in Africa). In this respect, a good number of investments in infrastructural projects serve China's efforts to secure its economic interests as well as its access to energy and strategic resources.

While it is obvious that the Chinese approach towards the developing world strongly differs from the EU one, it is important to recognise that the rise of China's presence should be put in context. While there is a strong increase in Chinese trade in most of the regions of the developing world, the EU still remains one of the main partners if one compares overall flows. Its share of Sub-Saharan Africa's trade, for instance, is still close to 50 per cent. The real impact of China's growing presence is also being challenged by the difficulty for the PRC to enhance its 'soft power' in the developing world. China today is facing a central question: how to use its re-born power? This question arises for every state when its power requires more space and resources. It also raises the question of how to define one's key values and objectives.

This book has shown that one of the main concerns of the PRC is to make sure that its partners in the developing world develop a positive view of China's re-emergence. It is only through reinforcing its 'soft power' that China can ensure the durability and stability of its relationship with the developing world. China disposes of various instruments to strengthen its soft power in this relationship: its cultural diplomacy, the attractiveness of the 'Beijing Consensus' as well as its regular emphasis on non-intervention. As regards the use of cultural diplomacy to reassure partners, it is obvious that China has not yet succeeded in softening its image and become truly attractive in the developing world, even though it has been very active in creating Confucius institutes, attracting students from developing countries to study in China, and developing a large network of Xinhua news agencies all around the world. In addition, the win-win dimension of the so-called Beijing Consensus model has been questioned to a large extent. The case of Latin America, where industrial production is at the heart of the local economy, shows that companies in Latin America face intense competition from Chinese firms, both in the field of high-technologies and in primary resources. Resentment is also engendered by the fact that China prefers to hire Chinese workers and imposes harsh working conditions. Finally, the nature of Latin America's exports to the PRC reinforces the position of Latin America as an exporter of primary resources and agricultural goods. In addition to these shortcomings, not all the regions believe in China's 'peaceful development' theory. This is particularly obvious for Southeast Asia, which has been especially concerned by China's growing militarism. Nevertheless, it can be submitted that the Chinese values of non-intervention are endorsed by a number of developing countries in 
Southeast Asia, Latin America and even Africa. This support opens up the possibility for the creation of a coalition of countries that do not share the contemporary Western understanding of sovereignty.

The difficulties China faces in its attempt to enhance its soft power show the continuous need for this country to clarify its interests and objectives as well as to enhance the transparency of its decision-making system. China's release of its first document regarding Latin America should be seen in this light. The establishment of a China-US dialogue on Latin America in 2006 also aims at clarifying the American and Chinese interests and political objectives in the region. The effect of this transparency effort is to reassure the US as well as countries in Latin America.

The key differences between the ways in which the EU and China act in the international arena demonstrate that developing countries are confronted with two competing models, two different ways of approaching the relationship between the developed, the emerging and the still developing worlds. This book shows that both models have their own merits and shortcomings. While the European model is increasingly criticised for its conditionality, which is sometimes perceived at best as paternalistic and contradictory with the practice of some of the EU's own Member States, and at worst as a form of neo-colonialism, China has to a large extent not succeeded in creating a consensus on its growing presence in the developing world.

\section{The Challenge of Establishing Triangular Dialogues}

Because of long-term structural factors, the developing world will become increasingly important for both China and the EU. The EU benefits from an incumbent position in terms of economic, diplomatic and cultural influence in most of the countries of the regions analysed except for East Asia. Nevertheless, given the path taken by its economy and demography, the EU cannot easily accept a weakening of its position in these regions. European economies are mature and their populations are stagnating, which means that apart from major exogenous technological shocks ${ }^{1}$ that cannot be predicted, the European economy is likely to experience slow growth for the next decades. The deleveraging process that has resulted from the financial crisis of 2008 will most likely continue for the next decade and generate an extra burden that will further weaken the prospects of European growth. Most of the additional growth for EU firms and for the EU economy is likely to come from the markets of the developing and emerging economies. Even if the Transatlantic Trade and Investment Partnership (TTIP) negotiations between the EU and the US were to be successful, they would not provide an alternative to the faster 
growth of the developing world. In that sense, the regions considered here are far more crucial today for the EU than they have been over the last six decades.

As for China, its need for raw materials, food and energy will continue to increase, albeit at a slower rate if the Chinese economy focuses increasingly on services and less on manufacturing industries, adopts energy and raw material-saving technologies and continues to experience a demographic slowdown. Securing resource-seeking investments will remain a key feature of Chinese diplomacy, trade and development policies. Furthermore, if Chinese firms continue to upgrade their innovation, marketing and international management know-how, they will pursue their internationalisation and engage in more market-seeking FDI in manufacturing and services. The penetration of developing economies by this type of Chinese FDI is already a first step in the transformation of Chinese firms into global MNEs and is likely to gain momentum in the next decade.

Without a stronger dialogue between the EU, China and the developing world, the absence of a consensus within the latter as well as the continuous need of the EU and China to increase their presence there in order to secure their economic, geo-strategic and development objectives, might lead to a potentially dangerous and increasingly unstable competition. However, if triangular dialogues are to be developed to manage these rising interdependencies, they will require some significant changes in China, the EU and the developing world.

If the EU aims to maintain the credibility of its multilateral rules-based governance model, it will have to accept a faster adaptation of multilateral institutions to reflect the growing economic and diplomatic weight of the emerging economies and notably China. This could provide an encouragement for China to adopt a strategy that would give greater weight to multilateral than bilateral initiatives. Regarding this evolution, the most important difficulty for European political and economic elites is to accept that the hegemonic historical position they have enjoyed for centuries has not only been challenged by the US since the 20th century but is now being challenged by China, a newcomer with different traditions, and potentially will be challenged further by other emerging powers like India in the course of this century. There is a temptation for European elites to try to maintain the status quo by strengthening their alliance with the US in order to maintain their hold on the multilateral system. The failure to impose their agenda in the Doha Round has led the US and the EU to develop the TTIP alternative, which aims to develop global standards by reaching a bilateral agreement that covers 40 per cent of the global economy. This strategy could be perceived as a 'West against the Rest' 
strategy and as a bid to maintain Western hegemony despite the recent evolutions of the world economy and demography. It is not out of the question that - if not accompanied by a new push for multilateral reforms in the sense indicated above - this approach may weaken the multilateral system and force China into a more defensive position that is likely to generate more tensions in the different regions analysed in this book.

Another necessary adaptation for Europe is to deal with the contradiction between the strategy of the EU proper and that of some of its Member States. The least one can say is that the use of hard power by some EU Member States, as in the case of Libya, Iraq or Ivory Coast, and the nontransparent diplomacies of some Member States which are at odds with the principles laid down at the supranational level by the EU institutions, do not encourage China to trust the EU as a credible partner in a triangular dialogue. This is a difficult issue as long as the EU Member States, notably the three big ones, continue to have many divergent economic and diplomatic interests. But precisely these divergences have so far limited the transfer of power to the EU level in the field of external relations.

Vis-à-vis the countries of the developing world, China will find it difficult to maintain its position of non-interference in domestic affairs as its investments grow and its firms and nationals have a sizeable impact on the local economies and societies. Its status as a 'developing' economy is already contested by many interest groups in developing countries, who consider that China's expansion might lead to greater economic dependence, which would not be so different from these countries' dependence on the European or US economies. With its massive economic rise, China is progressively reaching the limits of its 'trade only, win-win' strategy. China could trigger more protectionist reactions from local governments but also push incumbents like the EU and its Member States into a defensive posture, which could translate into a containment policy against China's expansion. To avoid this, China should participate and play a leading role in the strengthening and transformation of multilateral institutions, from the Western-based Bretton Woods system to a multilateralism that better reflects the recent shifts in the balance of economic and demographic power in the world.

\section{NOTE}

1. That is, a new drastic Schumpeterian innovation-driven growth cycle that would require major technological change, such as the development of an operational nuclear fusion industry, the generalisation of $3 \mathrm{D}$ printing in firms' production processes or major breakthroughs in bio-technology that would dramatically lower the price of healthcare. 


\section{REFERENCES}

Defraigne, Jean-Christophe (2012), 'China shakes the world: Challenges arising from shifts in the global balance of power', in Jean-Christophe Defraigne, Pierre Defraigne, Tanguy de Wilde and Jan Wouters (eds) The EU and Global Governance. Cheltenham, UK and Northampton, MA, USA: Edward Elgar Publishing.

Pomeranz, Kenneth (2000), The Great Divergence: China, Europe and the Making of the World Economy. Princeton, NJ: Princeton University Press.

Shambaugh, David (2013), China Goes Global: The Partial Power. Oxford, UK: Oxford University Press.

Wouters, Jan and Burnay, Matthieu (2013), 'The EU and Asia in the United Nations Security Council', in Thomas Christiansen, Emil Kirchner and Philomena Murray (eds) Handbook of EU-Asia Relations. Basingstoke, UK: Palgrave Macmillan. 